\title{
PODACI IZ STALIŠA DUŠA KAO IZVOR ZA ETNOLOŠKO ISTRAŽIVANJE OBITELJSKOGA ŽIVOTA KRIVOPUĆANA
}

\author{
Tihana RUBIĆ \\ Filozofski fakultet Sveučilišta u Zagrebu \\ Odsjek za etnologiju i kulturnu antropologiju \\ Ivana Lučića 3, 10000 Zagreb \\ Marinko VUKOVIĆ \\ Državni arhiv u Zagrebu \\ Opatička 29, 10000 Zagreb
}

\section{UVOD}

U prilogu donosimo podatke iz popisa kućanstava i stanovništva za razdoblje od 1770. do 1890. godine ${ }^{1}$, odnosno iz Stališa duša (lat. status animarum) župe Krivi Put. ${ }^{2}$

Cilj priloga je analizirati podatke o demografskim promjenama u naseljima: Krivi Put, Longovac, Šojatski Dolac, Veljun, Francikovac, Klarićevac, Vrataruša, Vodno i Šušanj ${ }^{3}$, te Mrzli Dolac ${ }^{4}$, te dinamiku promjena po pojedinom kućanstvu ${ }^{5}$ u stoljetnom razdoblju.

Broj članova obitelji po kućnom broju pratit ćemo za navedena naselja prema dvjema knjigama koje ukupno obuhvaćaju stoljetno razdoblje. Potom ćemo analizu nastaviti individualiziranijim pristupom, odnosno, pažnju ćemo usmjeriti na nekoliko primjera obitelji/kućanstava unutar pojedinih župskih naselja. Pratit ćemo mijene u strukturi i broju članova po pojedinome kućnome broju. U prvom dijelu priloga pokazat ćemo kretanje broja nuklearnih obitelji (roditeljski par s djecom) u stoljetnom razdoblju, za cijelo područje Župe (Tablice 1, 2 i 3). U drugom dijelu, ustvrdivši to kretanje, detaljno ćemo, uz prateće grafičke prikaze, opisati pojedine obiteljske „slučajeve“6: unutarnje promjene u pojedinim nuklearnim i višegeneracijskim obiteljima na jednom kućnom broju; životnu dob pojedinaca u trenutku sklapanja braka i rođenja prvog djeteta; broj djece u obitelji; učestalost smrtnosti novorođenčadi, male djece i rodilja; učestalost ponovnog sklapanja braka nakon smrti bračnoga druga te sklapanja braka unutar Župe i izvan nje.

1 Uzimaju li se u obzir godine rođenja upisanih osoba, podaci obuhvaćaju nešto uže razdoblje: od 1770 . do 1857. godine.

2 Prema korištenim Stališima duša (status animarum) koje obuhvaćaju razdoblje od 1770. do 1890. godine, Župi pripadaju sljedeća naselja za koja župnici bilježe podatke prema naseljima i kućnim brojevima: Krivi Put, Longovac, Sojatski Dolac, Veljun, Francikovac, Klarićevac, Vrataruša, Vodno i Šušanj, te Mrzli Dolac. Župa je u promatranom razdoblju obuhvaćala ukupno 9 naselja s pripadajućim zaselcima. U razdoblju koje promatramo naselju Krivi Put pripadali su zaselci: Anići, Gorica Krivoputska, Krivi Put, Longovac, Nikolići, Šošina, Šojatski Dolac, Špalji, Špinići, Zekanovići (Korenčić 1979: 603-605). Naselju Veljun (Primorski) pripadaju zaselci: Brezica, Burići, Donji Veljun, Francikovac, Francikovac-Matići, Gornji Veljun, Kuljići, Lopci, Lukci, Marinovići, Milčići, Petrovo, Rončevići, Šabani, Škopci, Veljun Primorski, Zečevi (ibid.). Naselju Mrzli Dol pripadaju zaselci: Katići, Kostići, Lipo Jela, Lučići, Mrzli Dol, Pavelići, Pavići, Rusova Draga, Stanić Breg, Tamburi (ibid.).

3 Ova su dva manja lokaliteta pisana zajedno u Stališima duša koje promatramo, zato ih i ovdje tako navodimo.

4 To je podjela prema naseljima koju za to razdoblje nalazimo u Stališima dǔsa koje promatramo. Mrzli Dolac naziv je za naselje koje se danas naziva Mrzli Dol.

5 Usporedi u prilogu Blaženke Ljubović o stanovništvu na području Krivoga Puta, str. 49, te u prilogu Mile Bogovića o povijesti Župe, str. 69-75. Oba priloga nalaze se u prvom svesku Monografije.

6 Vidi dijagrame obitelji dalje u nastavku rada. 
U konačnici, nastojimo uvidjeti kako stališi duša, kao izvor podataka, mogu pridonijeti istraživanju obiteljskog i društvenog života, te kao nadopuna već unaprijed poznatih podataka dobivenih putem terenskih istraživanja na krivoputskome području, a u okviru znanstvenoga projekta Identitet i etnogeneza primorskih Bunjevaca ${ }^{7}$.

\section{ISTRAŽIVANJE}

P odaci u etnološkim prilozima u prvom i drugom svesku Monografije odnose se mahom na razdoblje od početka 20. stoljeća do sedamdesetih godina 20. stoljeća ${ }^{8}$, dok se podaci koje promatramo iz stališa duša odnose na ranije razdoblje: od sredine 18. do sredine 19. stoljeća (od 1770. do 1890. godine). Naizgled se može činiti kako podaci prikupljeni terenskim etnološkim istraživanjem ${ }^{9}$ metodološki nisu usporedivi s onima koje donosimo iz stališa duša jer odgovaraju različitom vremenskom i povijesnom kontekstu. Tu različitost i promjenljivost prilika određuju primjerice: društvenopolitičke promjene, pokušaji pravne regulacije društvenih odnosa (zakon o diobama zadruga) te demografska kretanja stanovništva $^{10}$. Ipak, smatramo kako je ovim prilogom relevantno naznačiti neke uočene podudarnosti i poveznice među podacima iz ranijeg i kasnijeg razdoblja, onih koje smo sintetički utvrdili iz stališa duša, s onima prikupljenim etnološkim istraživanjem obiteljskog života Krivopućana, od početka 20. stoljeća do sedamdesetih godina. ${ }^{11}$

Razdoblje koje smo obuhvatili ovim prilogom bilježimo kao vrijeme već uhodanog vođenja evidencije župljana. Iako je vođenje vrste dokumenta kao što su stališi duša, propisano već stoljeće ranije ${ }^{12}, 1733$. godine je na inicijativu senjsko-modruškog biskupa Ivan Antuna Benzonija (1730-1745), a uz odobrenje cara Karla I., izvršena evidencija pojedinih župnika u biskupijama u svrhu utvrđivanja financijskih prilika pojedinačnih župa (Hoško 2004:367). Kako spominje u svom radu teolog Franjo Emanuel Hoško, “do 1733. godine dohoci župnika i kapelana prije svega su bili doprinosi vjernika” (ibid.:370), a na osnovu svojih evidencija župnici su bili dužni Svetoj Stolici redovito podnositi izvještaje (ibid.:375). Upravo dakle takve prilike, koje nazivamo uhodanim vođenjem evidencije župljana, prethode razdoblju koje smo obuhvatili u ovomu prilogu.

Arhivsko istraživanje ${ }^{13}$ proveli smo na temelju dviju knjiga: prva se sastoji od 240 rukom paginiranih stranica, a obuhvaća rođenja osoba od 1767. do 1852. godine, dok se druga sastoji od 60 stranica i obuhvaća rođenja osoba od 1800 . do 1895 . godine. Znatan dio podataka o rođenjima se iz jedne u drugu

U prilogu ćemo se posebno oslanjati na terenska etnološka istraživanja o migracijama (prilog Marijete Rajković u prvom svesku Monografije, str. 79-92), te obiteljskog života i odnosa (prilog Tihane Rubić i Danijele Birt u ovom svesku Monografije).

8 Vidi sve priloge u oba sveska Monografije, a posebno onaj o obiteljskom životu, odnosima i vrijednostima, suautorica Tihane Rubić i Danijele Birt u ovom svesku Monografije.

9 Terensko istraživanje provedeno je 2006. godine u selima: Krivi Put, Žuljevići i Šolići (koji pripadaju naselju Podbilo), Francikovac i Gornji Veljun (koji pripadaju naselju Veljun Primorski), te Pavići, Popići i Katići (koji pripadaju naselju Mrzli Dol). Vidi u bilješci priloga o obiteljskom životu, suautorica Tihane Rubić i Danijele Birt u ovom svesku Monografije.

10 Vidi više u prilogu Dragice Husanović-Pejnović i Dane Pejnovića u ovom svesku Monografije.

11 Pritom, za cjelovitiju analizu i komparaciju smatramo potrebnim razmotriti podatke kako iz stališa duša tako i drugih arhivskih dokumenata (matice rođenih, vjenčanih i umrlih). Isto tako, ti se podaci moraju odnositi i na kasnije razdoblje (20. stoljeće).

12 Vidi preciznije o Rimskom obredniku u nastavku priloga.

13 Na raspolaganju smo imali fotokopije stališa duša bez preciznih identifikacijskih oznaka i bibliografsih podataka. Stoga smo u početnoj fazi istraživanja sami identificirali, razgraničili, te odredili mjesta na koja se odnose, vremensko razdoblje koje obuhvaćaju, i za neke utvrdili broj stranica. Identificirali smo devet knjiga, prema sadržaju podataka u njima: Izvjestnice obiteljske iz Senja, 161 rukom paginirana stranica; Stališ duša župe Grada Senja 19./20. st.; Izvjestnice o rođenjima, smrtima, vjenčanjima za Senj 1925.-1943; Krivi Put - Status personalis, 60 rukom paginiranih stranica; Krivi Put (po mjestima): Malić, Alan, Francikovac, Veljun - rođenje, vjenčanje, smrt do 1870., 240 rukom paginiranih stranica. Na latinskom jeziku - broj domaćinstava, rođenje, vjenčanje i smrt, 19. stoljeće; Stališ duša 
knjigu preklapa jer je (prelaskom na iduću knjigu) uslijedilo djelomično rektificiranje podataka. Time se jedan dio podataka ponavlja, čime se otvara mogućnost provjere podataka iz prethodne knjige, te praćenja rasta i grananja pojedinačnih nuklearnih obitelji po kućnim brojevima.

Isprva je trebalo ustvrdili kretanje broja nuklearnih obitelji unutar jednog kućišta, za čitavo područje Župe (Tab. 1, 2, 3). ${ }^{14}$ Taj smo broj iščitali povezivanjem rodbinske pripadnosti (razlučivanjem i povezivanjem imena i prezimena osoba, te napomenama o rodbinskoj pripadnosti u odnosu na najstarijeg muškoga člana u jednoj nukleranoj obitelji). Time smo dobili broj obitelji po pojedinom kućištu unutar prvih pedeset godina (prva knjiga) i idućih pedeset godina (druga knjiga) (Tab. 1).

Istraživani uzorak jest statistički nedovoljan, što može dovesti u pitanje njegovu reprezentativnost za određeno zemljopisno područje. Ipak, smatramo kako preciznija kvantitativna istraživanja donose relevantne spoznaje o ukupnosti društvenih i demografskih procesa, no pokazuju manjak u prikazima „slučajeva“, što je pak cilj ovog priloga. Odlučili smo stoga izdvojiti nekoliko primjera obitelji iz različitih naselja, pritom ne pretendirajući na tumačenje istih kao obrasca življenja na području Krivoga Puta. ${ }^{15}$ Nastojali smo brojke i imena pretvoriti u jednu „obiteljsku priču“ i na taj način podatke iz ovog izvora promatrati prije svega iz etnološke perspektive. S druge strane, kako podaci iz stališa duša potkrepljuju naše ranije spoznaje, dobivene etnološkim, terenskim, istraživanjem na području Krivoga Puta, uvidjeli smo kako su ti podaci postali relevantnom dopunom i svojevrsnom potvrdom ranije obavljenog terenskog istraživanja obiteljskog života Krivopućana. ${ }^{16}$

Primjere obitelji iz različitih naselja pratit ćemo po pojedinim kućnim brojevima, onako kako su podaci i vođeni u ovom izvoru, a zanimat će nas struktura obitelji, promjene broja ukućana i sl. Broj kućanstava po naseljima odabran je ne toliko srazmjerno veličini ${ }^{17}$ naselja ${ }^{18}$, koliko kriterijem raznovrsnosti unutarobiteljskih prilika: tri kućanstva iz Krivoga Puta (k. br. 4, 23 i 41), te po jedno iz Šojatskoga Dolca (k. br. 53) i Veljuna (k. br. 68). ${ }^{19}$

\section{STALIŠI DUŠA: KRITIKA IZVORA}

$\mathrm{V}$ ažnost kvantitativnih izvora za proučavanje povijesti obitelji u Hrvatskoj na više je mjesta argumentirala i istaknula etnologinja Jasna Čapo Žmegač, baveći se gospodarstvenim i demografskim promjenama na hrvatskom selu kombinacijom kvantitativnih i kvalitativnih izvora (1996:190; 1996a:254). Pojedini suvremeni antropolozi također spregu kvantitativnih i kvalitativnih pristupa i izvora ističu kao nužnost u istraživanjima obiteljske i društvene povijesti u okvirima društveno-humanističkih znanosti (usp. Heady 2007).

Plovanije Krivoputske 1861. popisan po Ivanu Krstitelju Žaniću (1860-64); Stališ duša Krivi Put - 1829; te Stališ duša Župe senjske - 1889. s nadopisanom napomenom: "ne bijaše do sada nikakva", početak bilježenja podataka: od mjeseca kolovoza. Zbog velikog obima arhivske građe, u okviru vremena kojim smo raspolagali u pripremi ovoga priloga (tri mjeseca), odlučili smo se za obradu tek jednog dijela knjiga: pod rednim brojem 4 i 5 , koje su obuhvatile razdoblje po rođenjima od 1770. do 1890 . godine.

14 Arhivskim smo istraživanjem namjeravali isprva obuhvatiti širi vremenski raspon jer smo raspolagali s fotokopijama devet knjiga koje su sveukupno obuhvaćale razdoblje od sredine 18. do sredine 20. stoljeća. Ipak, ubrzo smo uvidjeli kako bi daljnja analiza znatno premašila okvire jednoga priloga, te smo reducirali istraživani okvir. Trebalo je ograničiti ili vremenski raspon ili broj naselja. Odlučili smo se za prvo, s ciljem da u analizu uključimo veći broj naselja, a da istraživanje ograničimo na stoljetno razdoblje. Riječ je o naseljima prema stališima duša za župu Krivi Put: Krivi Put, Longovac, Šojatski Dolac, Veljun, Francikovac, Klarićevac, Vrataruša, Vodno i Šušanj, te Mrzli Dolac.

15 O rezultatima demografskih istraživanja opširno i pregledno doznajemo iz priloga Dragice Husanović-Pejnović i Dane Pejnovića u ovom svesku Monografije.

16 Vidi prilog Tihane Rubić i Danijele Birt u ovom svesku Monografije.

17 Pritom mislimo na brojnost kuća unutar pojedinog naselja.

18 Vidi bilješku broj 12 i tablice 2 i 3 u ovome radu.

19 Svako smo kućanstvo u radu prikazali dijagramom. Vidi u nastavku rada. 
Stališ duša (lat. status animarum) je vrsta evidencijske župske knjige, crkvenog dokumenta u koji župnici bilježe broj kuća i populaciju unutar vlastite župe: broj obitelji po pojedinom kućnome broju, bračno stanje župljana, generalije o potomstvu i broj djece, godinu sklapanja braka te godinu smrti. ${ }^{20}$ Vođenje ove vrste crkvenoga dokumenta propisano je Rimskim obrednikom (Rituale Romanum) iz 1614. godine. ${ }^{21}$ Taj se dokument vodi ponajprije iz pastoralnih razloga, kao evidencija o znanju katekizma župljana, pregled nad vjerskim događanjima u župi, te u svrhu evidencije „stanja“ (broja živućih) župljana, s praktičnim ciljem - podmirivanja župskih daća.

Budući da primjena spomenutog obrednika nije bila obvezujuća, zapisi u stališima duša nemaju uniforman oblik, već ovise o osobi koja je podatke upisivala. Najstariji stališi dǔ̌a u Hrvatskoj potječu s kraja 18. stoljeća (iz sjeverozapadne Hrvatske). ${ }^{22}$ Zapisi u tim knjigama donose podatke o datumima rođenja (krštenja), vjenčanja i smrti svih članova jedne obitelji kroz više (dvije, tri, ponekad i četiri) generacija, dok su mjestimično zapisivani i podaci o: selidbama, udajama u drugu župu, te izvanbračnim vezama. Knjige su najčešće velikog formata, podijeljene po pojedinim selima i dijelovima župe, a najčešće je jedna stranica posvećena jednom kućanstvu. Prve su knjige, sredinom 18. stoljeća, vođene deskriptivno, dok se stotinjak godina kasnije počinje uvoditi tabelarni prikaz s nazivima stupaca, pa je dužnost osobe koja upisuje podatke upisati ih na odgovarajuće mjesto. Za identifikaciju svakog kućanstva uvode se podaci o: mjestu i kućnom broju kućanstva ${ }^{23}$, imenu i prezimenu gospodara (rodonačelnika), podaci o ostalim

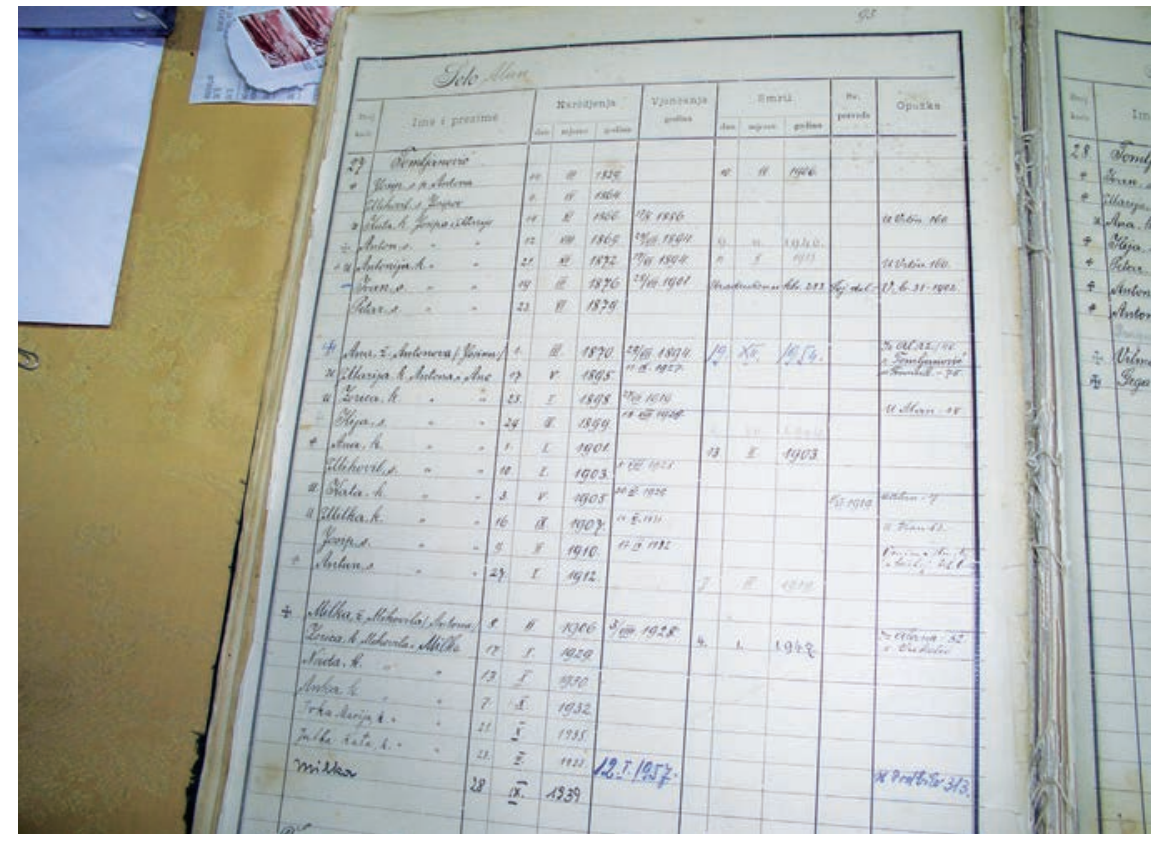

Slika 1: Tablično vođenje podataka. Primjer stranice knjige Stališa duša ̌̌upe Krivi Put; snimila B. Ljubović, Gradski muzej Senj, 2009.

20 Župnici su se za područje Krivoga Puta u razdoblju od 1795. godine do danas smjenjivali raznovrsnom dinamikom: neki su župnikovali četiri godine (župnici Ivan Žanić i Rikard Valić), a neki gotovo četiri desetljeća (primjerice Petar Mažuranić) (usp. prilog Mile Bogovića u prvom svesku Monografije, str. 72-73).

21 Izvor: http://rodoslovlje.bloger.hr/post/status-animarum/57376.aspx

22 Isti izvor.

23 Kućanstvo (kućni broj) predstavlja funkcionalno središte ispunjavanja elementarnih potreba i interesa njegovih članova (Čapo 1991:92). U demografskim se radovima terminom kućanstvo označava jedna ili više obitelji u zajedničkom stambenom objektu (kući), a terminom obitelj manje jedinice unutar kućanstva ili kućanstvo koje se sastoji od samo jedne obitelji (ibid.:89). Ovom razdiobom u određenju vodit ćemo se i u ovom prilogu, ali pritom podvlačimo kako termin kućanstvo ne 
članovima obitelji i njihovom srodstvu u odnosu na gospodara, kao i o slugama u kućanstvu (npr. kod plemićkih obitelji). Zapisi su na latinskom jeziku vođeni do 1847 . godine. ${ }^{24}$

Knjige kojima smo raspolagali imale su takav, unaprijed zadan, tabelarni okvir u koji su upisivani podaci. Te je knjige puno lakše čitati i pretraživati, nego one deskriptivne. U takvim knjigama vrlo često svaki član kućanstva dobiva i određenu oznaku ${ }^{25}$, prema svom srodničkome statusu unutar obitelji. ${ }^{26}$ Ipak, knjige kojima smo raspolagali nisu imale posebnih oznaka, već su upisivani rodbinski nazivi (na latinskom ili hrvatskom jeziku) kojima je jasno označavano linearno srodstvo pojedinoga člana, definirano uvijek u odnosu na rodonačelnika, najstarijeg muškaraca: žena (uxor), kćer (filia), sin (filius).

J. Čapo Žmegač se u studiji gospodarstvenih i demografskih promjena hrvatskoga sela, na primjeru vlastelinstva Cernik, iscrpno koristila podacima iz demografskih izvora, a u istraživanju je koristila spregu više vrsta izvora, među kojima i statuse animarume. Osvrnula se onda i na (ne)pouzdanosti ove vrste crkvenog dokumenta kao izvora za istraživanje te utvrđivanje obiteljskih i demografskih promjena u prošlosti (usp. Čapo 1991). Njezina se kritika podudara s poteškoćama na koje smo sami nailazili pri obradi stališa duša za župu Krivi Put. Elementarna poteškoća pri korištenju ovakve vrste arhivskog gradiva kao izvora za obiteljsku povijest leži već u činjenici da su župnici, katkad i nekoliko puta na istome mjestu, dopunjavali i/ili ispravljali već upisane podatke ${ }^{27}$, što uvelike otežava čitanje i razumijevanje podataka.

Drugo, iz ovog se izvora ne može sa sigurnošću reći od kada je neka obitelj obitavala na području Župe, odnosno, kada je doselila na ove prostore. Za to bi trebalo konzultirati ostale vrste arhivskih izvora, kao što su matice rođenih, umrlih i vjenčanih, u kojima su zastupljeni precizniji podaci, također vođeni prema pojedinim kućnim brojevima. ${ }^{28}$ Temeljem ove vrste izvora nemoguće je provjeriti tko je bio rodonačelnikom pojedine nuklearne obitelji po doseljenju na ovo područje.

Također, prema stališima duša nemoguće je ustvrditi imovinskopravne i radne odnose unutar obitelji na pojedinom kućnome broju. Vodeći se etnološkim razlikovanjem nuklearnih od zadružnih obitelji

možemo valjano primijeniti na pojedinu kuću (stambeni objekt na pojedinom kućnom broju) jer iz izvora koje koristimo ne iščitavamo ništa o unutarnjim odnosima unutar pojedine kuće. Kućanstvo promatramo prije svega kao funkcionalnu jednicu unutar koje se odvija određen suživot barem u nekoj mjeri (zajednički ulaz, zajedničko vlasništvo nad objektom i dr.), bez obzira na željenost takvog suživota i tendenciju iseljavanja. Vidi o tome opširnije u prilogu Tihane Rubić i Danijele Birt o obiteljskim odnosima u ovom svesku Monografije, poglavito u odlomku naslova Suživot dviju nuklearnih obitelji.

24 Na posljednjem Hrvatskom staleškom saboru održanom 23. listopada 1847. godine hrvatski je proglašen "diplomatičkim jezikom" to jest službenim, a na temelju čl. 120 Statuta staleža i redova kraljevina Hrvatske, Slavonije i Dalmacije iz 1715. godine kojim su utvrdena prava Hrvatske. (Kolanović 1995:59).

25 Izvor: http://rodoslovlje.bloger.hr/post/status-animarum/57376.aspx.

26 Predviđeno je da svaki odrasli član kućanstva dobiva oznaku - veliko slovo - radi identifikacije rodbinskih odnosa. Primjerice, par je dobio oznaku A. Njihova su djeca dobivala oznaku malog slova - u ovom primjeru malo a. Drugi par u kućanstvu dobio bi oznaku B, njihova djeca oznaku b, itd. S protokom vremena, kako bi se tko od djece vjenčao, uz prethodnu oznaku dobio bi novo, veliko slovo, npr. K i bilo bi dopisano ime osobe s kojom je vjenčan. Njihova bi djeca bila upisana pod malim slovom k. Kada bi netko umro, u odgovarajuću rubriku bio bi upisan datum smrti, a njegovo ime obično bi bilo prekriženo. Ipak, treba reći kako knjige koje smo analizirali u ovom radu ne sadrže sve podatke i oznake koji se ovdje navode.

27 Primjerice, bilježili su rođenje, vjenčanje i smrt župljana, zatim križali obitelji ili članove koji su odselili ili nadopisivali mjesto iz kojeg se žena udala. No često svi ovi podaci nisu bili unošeni, pa primjerice podatke o iseljavanju imamo samo u fragmentima. Isto tako, uzroci smrti samo su katkad bilježeni tako da o nezabilježenim uzrocima smrti iz ovih izvora možemo samo nagađati.

28 Za potpuno razumijevanje odnosa unutar kućanstva potrebna je iscrpnija etnografska građa i poznavanje društvenokulturnog konteksta u kojem je izvor nastao. 
kriterijem imovinskopravnih i/ili radnih odnosa, a ne mnogobrojnosti obiteljskih članova po jednom kućnom broju ${ }^{29}$, prisutnost više nuklearnih obitelji u jednom vremenskom razdoblju na jednom kućnom broju (što možemo iščitati iz ovih izvora), ne govori nužno u prilog da je obitelj bila zadružna. ${ }^{30}$

Nadalje, nedostaju podaci o horizontalnom i dijagonalnome srodstvu članova obitelji po pojedinom kućištu te unutar naselja i unutar cijele Župe, kao što je i nemoguće ustvrditi vrstu međusobnog srodničkih odnosa ${ }^{31}$ članova iz različitih nuklearnih obitelji po jednom kućnome broju jer ne znamo u kojem su srodničkom odnosu najstariji muški članovi, oni od kojih se granaju daljnji podaci. Možemo taj odnos samo pretpostaviti ili provjeriti u ostalim izvorima, primjerice, matičnim knjigama.

Do podataka poput učestalosti smrti novorođenčadi i male djece, ponovnog sklapanja braka nakon smrti jednog od supružnika, smrti žena pri porodu i sl. iz ove vrste izvora možemo doći tek posrednim i sintetičkim zaključivanjem, ali pritom imajući na umu moguću nepotpunost (ili nečitljivost) svih podataka.

Stališi duša također tek sporadično sadržavaju podatke o nečijem zanimanju: vojnik (soldat) ili o iseljavanju: otišao u Senj ${ }^{32}$.

\section{4. ŠTO DOZNAJEMO IZ STALIŠA DUŠA ŽUPE KRIVI PUT?}

$\mathrm{P}$ ogledamo li krivoputska naselja od 1770. do 1890. godine, vidljivo je da sva naselja (Krivi Put, Longovac, Šojatski Dolac, Veljun, Francikovac, Klarićevac, Vrataruša, Vodno i Šušanj) imaju numerirane kućne brojeve u jednoj brojčanoj skali (3-93) 33. Primjerice, Krivi Put završava s brojem 45 pa se nastavlja na broju 91; naselje Longovac je od kućnog broja 46 do 50; itd. Mrzli Dolac jedino ima 16 kućnih brojeva (drugo najveće naselje iz Krivoga Puta) i on je pisan zasebno, od broja 1 do 16. (Tab. 1)

29 Kućanstvo smo, kao zasebnu jedinicu stanovanja, identificirali na temelju kućnih (rednih) brojeva (koji se nižu na lijevoj strani svake stranice knjige), ali i imena i prezimena osoba te pripadajućih im napomena o linearnom srodstvu (žena, kćer, sin), koje polaze od njihove pripadnosti u odnosu na najstarijeg muškog člana (usp. Čapo 1991:75-87).

30 Već je etnolog Milovan Gavazzi upozorio na činjenicu da kod zadruge nije bitan broj članova, nego da se radi o načelu nepodijeljenoga odnosno nedjeljivoga zajedničkog imutka, o zajedničkom gospodarenju, o podjednakom korištenju svih zadružnih dobara za sve članove, o poštivanju određenih pravila prigodom (načelno moguće) diobe toga imutka. (1978:82).

31 O poimanju rodbinskih odnosa (u bližem i daljem smislu) vidi više u prilogu o obiteljskom životu, u odlomku o rodbinskim nazivima, suautorica Tihane Rubić i Danijele Birt u ovom svesku Monografije.

32 Podaci su najčešće pisani u natukničkim formulacijama i nečitkim rukopisom.

33 Kućanstva su numerirana rednim brojevima u knjigama, a kreću se od rednog broja tri. Župni stan i crkva u Podbilu vode se pod rednim brojem 1 i 2. 


\begin{tabular}{|c|c|c|c|}
\hline Župsko naselje & Kućni broj & $\begin{array}{l}\text { Broj obitelji u razdoblju } \\
\text { 1770-1852. g. i 1800-1890. g. }\end{array}$ & $\begin{array}{l}\text { Promjena broja obitelji } \\
\text { u stoljetnome razdoblju }\end{array}$ \\
\hline \multirow{45}{*}{ KRIVI PUT } & $1^{34}$ & crkva & \\
\hline & 2 & župni stan & \\
\hline & 3 & $7^{35}(3)^{36}$ & -4 \\
\hline & 4 & $5(2)$ & -3 \\
\hline & 5 & $4(3)$ & -1 \\
\hline & 6 & $3(3)$ & 0 \\
\hline & 7 & $3(3)$ & 0 \\
\hline & 8 & $3(9)$ & +6 \\
\hline & 9 & $2(1)$ & -1 \\
\hline & 10 & $2(3)$ & +1 \\
\hline & 11 & $1(5)$ & +4 \\
\hline & 12 & $1(1)$ & 0 \\
\hline & 13 & $1(2)$ & +1 \\
\hline & 14 & $1(1)$ & 0 \\
\hline & 15 & $2(3)$ & +1 \\
\hline & 16 & $3(3)$ & 0 \\
\hline & 17 & $1(4)$ & +3 \\
\hline & 18 & $3(4)$ & +1 \\
\hline & 19 & $1(1)$ & 0 \\
\hline & 20 & $4(2)$ & -2 \\
\hline & 21 & $3(4)$ & +1 \\
\hline & 22 & $1(2)$ & +1 \\
\hline & 23 & $6(12)$ & +6 \\
\hline & 24 & $6(2)$ & -4 \\
\hline & 25 & $1(1)$ & 0 \\
\hline & 26 & $4(3)$ & -1 \\
\hline & 27 & $3(2)$ & -1 \\
\hline & 28 & $2(3)$ & +1 \\
\hline & 29 & $3(3)$ & 0 \\
\hline & 30 & $5(1)$ & -4 \\
\hline & 31 & $3(1)$ & -3 \\
\hline & 32 & $6(1)$ & -5 \\
\hline & 33 & $2(5)$ & +3 \\
\hline & 34 & $4(1)$ & -3 \\
\hline & 35 & $1(2)$ & +1 \\
\hline & 36 & $7(4)$ & -3 \\
\hline & 37 & $3(1)$ & -2 \\
\hline & 38 & $4(3)$ & -1 \\
\hline & 39 & $1(1)$ & 0 \\
\hline & 40 & $5(6)$ & +1 \\
\hline & 41 & $4(8)$ & +4 \\
\hline & 42 & $2(2)$ & 0 \\
\hline & 43 & $7(6)$ & -1 \\
\hline & 44 & $3(1)$ & -2 \\
\hline & 45 & $2(2)$ & 0 \\
\hline \multirow{5}{*}{ LONGOVAC } & 46 & $4(2)$ & -2 \\
\hline & 47 & $1(1)$ & 0 \\
\hline & 48 & $2(2)$ & 0 \\
\hline & 49 & $1(1)$ & 0 \\
\hline & 50 & $1(1)$ & 0 \\
\hline
\end{tabular}

34 Stališi duša ne započinju rednim brojem 1, već rednim brojem 3. Brojevi 1 i 2 odnose se na crkvu i župni stan.

35 Broj izvan zagrade označava broj obitelji u pojedinom kućanstvu u razdoblju od 1770. do 1857. godine.

36 Broj u zagradi označava broj obitelji u pojedinom kućanstvu u razdoblju od 1800. do 1890. godine. 


\begin{tabular}{|c|c|c|c|}
\hline \multirow{9}{*}{$\begin{array}{l}\text { ŠOJATSKI } \\
\text { DOLAC }\end{array}$} & 51 & $3(4)$ & +1 \\
\hline & 52 & $1(1)$ & 0 \\
\hline & 53 & $4(5)$ & +1 \\
\hline & 54 & $2(1)$ & -1 \\
\hline & 55 & $1(3)$ & +2 \\
\hline & 56 & $2(1)$ & -1 \\
\hline & 57 & $4(4)$ & 0 \\
\hline & 58 & $4(4)$ & 0 \\
\hline & 59 & $3(2)$ & -2 \\
\hline \multirow{12}{*}{ VELJUN } & 60 & $1(1)$ & 0 \\
\hline & 61 & $4(5)$ & +1 \\
\hline & 62 & $3(3)$ & 0 \\
\hline & 63 & $4(3)$ & -1 \\
\hline & 64 & $2(3)$ & +1 \\
\hline & 65 & $1(2)$ & +1 \\
\hline & 66 & $5(4)$ & -1 \\
\hline & 67 & $2(3)$ & +1 \\
\hline & 68 & $8(6)$ & -2 \\
\hline & 69 & $4(2)$ & -2 \\
\hline & 70 & $3(2)$ & -1 \\
\hline & 71 & $2(2)$ & 0 \\
\hline \multirow{7}{*}{ FRANCIKOVAC } & 72 & $4(2)$ & -2 \\
\hline & 73 & $6(4)$ & -2 \\
\hline & 74 & $2(3)$ & +1 \\
\hline & 75 & $2(3)$ & +1 \\
\hline & 76 & $1(3)$ & +2 \\
\hline & 77 & $2(2)$ & 0 \\
\hline & 78 & $3(2)$ & -1 \\
\hline \multirow{4}{*}{ KLARIĆEVAC } & 79 & $2(2)$ & 0 \\
\hline & 80 & $7(4)$ & -3 \\
\hline & 81 & $1(2)$ & +1 \\
\hline & 82 & $4(6)$ & +2 \\
\hline \multirow{5}{*}{ VRATARUŠA } & 83 & $6(7)$ & +1 \\
\hline & 84 & $5(7)$ & +2 \\
\hline & 85 & $2(2)$ & 0 \\
\hline & 86 & $4(1)$ & -3 \\
\hline & 87 & $2(1)$ & -1 \\
\hline \multirow{3}{*}{$\begin{array}{l}\text { VODNO i } \\
\text { ŠUŠANJ }\end{array}$} & 88 & $1(1)$ & 0 \\
\hline & 89 & $2(3)$ & +1 \\
\hline & 90 & $2(2)$ & 0 \\
\hline KRIVI PUT & 91 & $2(2)$ & 0 \\
\hline $\begin{array}{c}\text { ŠOJATSKI } \\
\text { DOLAC }\end{array}$ & 92 & $3(5)$ & +2 \\
\hline VELJUN & 93 & $4(5)$ & +1 \\
\hline
\end{tabular}




\begin{tabular}{|c|c|c|c|}
\hline \multirow{4}{*}{} & 1 & $6(4)$ & -2 \\
\cline { 2 - 4 } & 2 & $6(17)$ & +11 \\
\cline { 2 - 4 } & 3 & $5(6)$ & +1 \\
\cline { 2 - 4 } & 4 & $4(2)$ & -2 \\
\cline { 2 - 4 } & 5 & $11(6)$ & -5 \\
\cline { 2 - 4 } & 6 & $5(1)$ & +1 \\
\cline { 2 - 4 } & 7 & $4(5)$ & -1 \\
\cline { 2 - 4 } & 8 & $2(1)$ & +2 \\
\cline { 2 - 4 } & 9 & $2(4)$ & -3 \\
\cline { 2 - 4 } & 10 & $1(2)$ & -6 \\
\cline { 2 - 4 } & 11 & $7(4)$ & -3 \\
\cline { 2 - 4 } & 12 & $8(2)$ & +2 \\
\cline { 2 - 4 } & 13 & $4(1)$ & +2 \\
\cline { 2 - 4 } & 14 & $4(6)$ & +1 \\
\cline { 2 - 4 } & 15 & $4(6)$ & $2(3)$ \\
\hline
\end{tabular}

Tablica 1: Promjena broja obitelji u krivoputskim naseljima od 1770. do 1890. godine. Tablicu, prema podacima iz Stališa duša, izradili T. Rubić i M. Vuković, 2009.

Ovo je bila prva tablica koju smo izradili na osnovu podataka iz Stališa duša. Pobrojali smo nuklearne obitelji po pojedinačnim kućnim brojevima u promatranom razdoblju. Potom smo prebrojali koliko nuklearnih obitelji u prvom peedesetogodišnjem razdoblju živi na svakom kućnom broju, u svim naseljima, a to smo učinili i za iduće pedesetgodišnje razdoblje. Iz toga su proizašle tablice 2 i 3, iz kojih je bilo razvidno kako je postojanje dviju nuklearnih obitelji na jednom kućnome broju daleko najprisutniji oblik stanovanja u promatranom razdoblju, a da su mnogoobiteljska kućanstva na području Župe bila rijetkost. Možebitno je riječ da je suživot dviju nuklearnih obitelji po kućanstvu, uočen kao oblik stanovanja koji prednjači nad ostalima, upravo onaj suživot dviju nuklearnih obitelji - dvojice braće sa ženom i djecom koji je često i bio spominjan od Krivopućana tijekom terenskog istraživanja obiteljskog života. ${ }^{37}$ (Tab. 2, 3) Taj se podatak, zabilježen za područje Krivoga Puta, djelomično podudara s ranijim razmatranjima J. Čapo Žmegač da je iz statističkih, kvantitativnih analiza razvidno kako su nuklearne (mali broj članova po kućištu) u Hrvatskoj u tom razdoblju prevladavale ${ }^{38}$, iako u etnografskim radovima u 20. stoljeću pretežu opisi velikih obitelji $i$ kućanstava s više bračnih parova, tzv. zadruga, te izostaju opisi života u malim obiteljima koje su već početkom 20. stoljeća dominirale na širokom hrvatskom području39 (1998:253). Ovdje nije riječ o nuklearnoj obitelji po jednom kućnom broju, već o dvije nuklearne obitelji, pri čemu su najstariji muški članovi braća. Iz Stališa duša mi ne možemo provjeriti tu srodničku pripadnost dvojice najstarijih muških članova (rodonačelnika), jer ona ničim nije naznačena, ali možemo pretpostaviti da je bila riječ o dvojici braće na temelju vrlo često spominjanih primjera s terenskog istraživanja. Pritom, važno je spomenuti, takav suživot najčešće nije bio po volji dvjema obiteljima jer je bila prisutna stalna tendencija razdvajanja (iseljenja jedne od nuklearnih obitelji s kućišta), primjerice, uslijed čestih neslaganja. ${ }^{40}$ Ona je

37 Vidi prilog naslova Obiteljski život, odnosi i vrijednosti, suautorica Tihane Rubić i Danijele Birt, u ovom svesku Monografije.

38 Čapo Žmegač 1998: 254.

39 J. Čapo Žmegač upozorava da i zato što su etnolozi tragali samo za velikim kućanstvima, nastao je manjak, gotovo (...) apsolutni nedostatak za sva hrvatska područja opisa života malih obitelji, a u jadranskoj zoni obitelji općenito. (ibid.)

40 Usporedi posljednji odlomak o mogućim sukobima u obitelji, u prilogu Tihane Rubić i Danijele Birt u ovom svesku Monografije. 
bila odraz siromaštva i materijalne oskudice, koji se bez iznimke od strane Krivopućana povezuju s ovim zemljopisnim područjem, za sva razdoblja. ${ }^{41}$

Iz analize dviju knjiga za župu Krivi Put (prva knjiga obuhvaća razdoblje rođenja od 1770. do 1857. godine, a druga razdoblje rođenja od 1800. do 1890. godine) uočava se porast broja kućanstava (kućnih brojeva) unutar Župe. Tako se za naselje Mrzli Dol u razdoblju do 1857. godina bilježi 16 kućnih brojeva, dok se u prvoj polovici 19. stoljeća taj broj gotovo utrostručuje (40). Krivi Put je, kao jedno od triju najvećih župskih naselja ${ }^{42}$ u tom razdoblju, do 1857 . godine, imao 46 kućnih brojeva, a potom se u prvoj

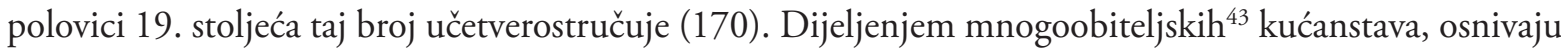
se nova i pridružuju im se novi kućni brojevi. ${ }^{44}$

\begin{tabular}{|l|c|c|c|c|c|c|c|c|c|c|c|c|c|}
\hline $\begin{array}{l}\text { Broj obitelji po } \\
\text { kućanstvu }\end{array}$ & 1 & 2 & 3 & 4 & 5 & 6 & 7 & 8 & 9 & 10 & 11 & $\begin{array}{c}\text { Kućni } \\
\text { brojevi }\end{array}$ & $\begin{array}{c}\text { Ukupno } \\
\text { kuća }\end{array}$ \\
\hline KRIVI PUT & 10 & 7 & 11 & 6 & 3 & 3 & 3 & -- & -- & -- & -- & $3-45,91$ & 43 \\
\hline LONGOVAC & 3 & 1 & -- & 1 & -- & -- & -- & -- & -- & -- & -- & $46-50$ & 5 \\
\hline ŠOJATSKI DOLAC & 2 & 2 & 3 & 3 & -- & -- & -- & -- & -- & -- & -- & $51-59,92$ & 10 \\
\hline VELJUN & 2 & 3 & 2 & 4 & 1 & -- & -- & 1 & -- & -- & -- & $60-71,93$ & 13 \\
\hline FRANCIKOVAC & 1 & 3 & 1 & 1 & -- & 1 & -- & -- & -- & -- & -- & $72-78$ & 7 \\
\hline KLARIĆEVAC & 1 & 1 & -- & 1 & -- & -- & 1 & -- & -- & -- & -- & $79-98$ & 4 \\
\hline VRATARUŠA & -- & 2 & -- & 1 & 1 & 1 & -- & -- & -- & -- & -- & $83-87$ & 5 \\
\hline VODNO IŠUŠANJ & 1 & 2 & -- & -- & -- & -- & -- & -- & -- & -- & -- & $88-90$ & 3 \\
\hline MRZLI DOLAC & 1 & 3 & -- & 5 & 2 & 2 & 1 & 1 & -- & -- & 1 & $1-16$ & 16 \\
\hline Ukupno Svi lokaliteti & 21 & 24 & 17 & 22 & 7 & 7 & 5 & 2 & -- & -- & 1 & & 106 \\
\hline
\end{tabular}

Tablica 2: Prva knjiga, Stališ duša za そ̌upu Krivi Put; vremenski raspon 1770-1857. Tablicu, prema podacima iz Stališa duša, iærradila T. Rubić, 2009.

Vidljivo je da na području Župe (ukupno 106 kuća) suživot dviju nuklearnih obitelji po pojedinom kućnom broju predstavljao najučestaliji oblik stanovanja. Visok je broj kućanstava s jednom nuklearnom obitelji, te tri i četiri nuklearne obitelji po jednom kućištu. Samo je jedan kućni broj imao jedanaest nuklearnih obitelji u pedesetogodišnjem razdoblju, dva su kućna broja imala po osam nuklearnih obitelji po jednom kućištu, pet ih je imalo sedam nuklearnih obitelji, a pet i šest nuklearnih obitelji imalo je ukupno četrnaest kuća (svaki po sedam).

${ }_{41}$ Usporedi primjerice odlomak o utjecaju siromaštva na obiteljski život, u prilogu Tihane Rubić i Danijele Birt u ovom svesku Monografije.

42 S Veljunom i Francikovcem. Usporedi podatak u prilogu Mile Bogovića o povijesti Župe, u prvom svesku Monografije, str. 70 .

43 Mislimo na više nuklearnih obitelji.

${ }^{4}$ U trećem tabličnom prikazu ipak nismo obradili taj broj kuća koji je činio razliku u povećanju kućnih brojeva u odnosu na ranije pedesetogodišnje razdoblje. Željeli smo se zadržati na istom broju kuća (106), kako bismo mogli promotriti promjene, koje su se dogodile obzirom na povećanja ili smanjenja broja nuklearnih obitelji po pojedinom kućištu, u ovom stoljetnom razdoblju. 


\begin{tabular}{|l|c|c|c|c|c|c|c|c|c|c|c|c|c|c|c|}
\hline $\begin{array}{l}\text { Broj obitelji po } \\
\text { kućanstvu }\end{array}$ & 1 & 2 & 3 & 4 & 5 & 6 & 7 & 8 & 9 & 10 & 11 & 12 & 17 & Kuć. br. & $\begin{array}{c}\text { Ukupno } \\
\text { kuća }\end{array}$ \\
\hline KRIVI PUT & 12 & 9 & 11 & 4 & 2 & 2 & -- & 1 & 1 & -- & -- & 1 & -- & $3-45,91$ & 43 \\
\hline LONCOVAC & 3 & 2 & -- & -- & -- & -- & -- & -- & -- & -- & -- & -- & -- & $46-50$ & 5 \\
\hline ŠOJATSKI DOLAC & 3 & 1 & 1 & 3 & 2 & -- & -- & -- & -- & -- & -- & -- & -- & $51-59,92$ & 10 \\
\hline VELJUN & 1 & 4 & 4 & 1 & 2 & 1 & -- & -- & -- & -- & -- & -- & -- & $60-71,93$ & 13 \\
\hline FRANCIKOVAC & -- & 3 & 3 & 1 & -- & -- & -- & -- & -- & -- & -- & -- & -- & $72-78$ & 7 \\
\hline KLARIĆEVAC & -- & 2 & -- & 1 & -- & 1 & -- & -- & -- & -- & -- & -- & -- & $79-98$ & 4 \\
\hline VRATARUŠA & 2 & 1 & -- & -- & -- & -- & -- & -- & -- & -- & -- & -- & -- & $83-87$ & 5 \\
\hline VODNO I ŠUŠANJ & 1 & 1 & 1 & -- & -- & -- & -- & -- & -- & -- & -- & -- & -- & $88-90$ & 3 \\
\hline MRZLI DOLAC & 3 & 3 & 1 & 3 & 1 & 4 & -- & -- & -- & -- & -- & -- & 1 & $1-16$ & 16 \\
\hline $\begin{array}{l}\text { Ukupno SVi } \\
\text { lokaliteti }\end{array}$ & 25 & 26 & 21 & 13 & 8 & 2 & 1 & 1 & -- & -- & -- & 1 & 1 & & 106 \\
\hline
\end{tabular}

Tablica 3: Druga knjiga, Stališ duša; vremenski raspon 1800-1890. Tablicu iæradila T. Rubić.

Iz ove, druge tablice, za čitavo područje Župe, također promatramo isti broj kuća (106) i primjećujemo kako je ponovno suživot dviju nuklearnih obitelji po pojedinom kućnom broju prednjačio nad ostalim oblicima stanovanja, posebno onima koji bilježe više od pet nuklearnih obitelji po kućištu, a da ne govorimo o onima koji broje, primjerice, 12 nuklearnih obitelji po kućnome broju (Krivi Put) ili čak 17 (Mrzli Dolac). Konkretno, za ovu posljednju, mnogoobiteljsku i mnogoljudnu zajednicu stanovanja, iz ove vrste izvora nemamo podataka koji bi mogli govoriti u prilog tome da je ta obitelj bila zadružna, iako je za pretpostaviti. Ali, mi to ne možemo tvrditi. Tek terenskim istraživanjem i komparacijom više vrsta izvora možemo uvidjeti unutarnje gospodarstvene, imovinske i radne odnose koji nam mogu posvjedočiti da je ta obitelj bila zadružna. ${ }^{45}$

$\mathrm{Na}$ osnovu podataka iz izvora uvidjeli smo, dakle, kako je najveći broj kućanstava u svim župskim naseljima sastavljen od jedne do četiri obitelji. Uočljivo je kako broj kućanstava s manjim brojem obitelji (jedna do tri), i broj onih s pet obitelji, oko sredine 19. stoljeća raste, dok se broj kućanstava s četiri, šest, sedam, osam i više obitelji smanjuje. Osim toga uočavamo pojavu dvaju kućnih brojeva s velikim brojem obitelji (od dvanaest i sedamnaest obitelji). Navedeno je u skladu s poznatim spoznajama o demografskim promjenama u promatranom razdoblju. To je vrijeme porasta broja obitelji po kućištu, ali i porasta dioba obiteljskih zadruga općenito u Hrvatskoj, u vrijeme agrarne krize (Pavličević 1989: 262).

Godine 1857. proveden je prvi moderni popis stanovništva na području tadašnje Austrije ${ }^{46} \mathrm{i}$ tada se i bilježi porast stanovnika, trend koji se nastavlja sve do kraja 19. stoljeća. ${ }^{47}$ Iz Stališa duša koje promatramo razvidno je da u drugoj polovici 19. stoljeća dolazi do porasta broja stanovnika, što se podudara s

45 Da je ipak riječ o obiteljskoj zadruzi, konkretno za ovaj slučaj, ne potvrđuje nam ovaj izvor, već dokumenti poput onih koji svjedoče o njihovoj diobi. Dioba kućišta Prpić na kućnom broju 2 iz Mrzloga Dola, dokumentirana je u spisu koji se čuva u Hrvatskom državnom arhivu u Zagrebu, a koji navodi povjesničar Dragutin Pavličević u svojoj studiji: Naša zadruga Prpić, kbr. 2 u Mrzlom dolu, podijeljena je tajno na 19 dijelova, a broji 180 duśa, te smo se već razrodili, da se i medusobno ženimo. (Pavličević 1989:83). Ovo kućanstvo (seljačka obiteljska zadruga) po tipologiji podijeljenosti pripada tajno podijeljenima. (Pavličević 1989:77). Za ostala kućanstva na području župe Krivi Put zasad, prema našim saznanjima, nema takvih podataka, premda bi cjelokupnu arhivsku građu za područje Krivoga Puta, a pohranjenu u Arhivu, tek trebalo sustavno i temeljito grupirati i istražiti.

46 Usporedi prilog Blaženke Ljubović u prvom svesku Monografije, str. 50; te Dragice Husanović-Pejnović i Dane Pejnovića u ovom svesku Monografije.

47 Usporedi prilog Dragice Husanović-Pejnović i Dane Pejnovića u ovom svesku Monografije. 
podacima iz spomenutoga popisa. Moglo bi se pomisliti kako uslijed spomenutih demografskih promjena i povećanja članova obitelji po pojedinom kućištu (koje postaje prenapučenim), raste i broj kućišta (kućnih brojeva) u pojedinom naselju. Međutim, primjećujemo da se broj članova obitelji nije povećavao jednako u svim kućištima: dok na nekima broj obitelji u stogodišnjem razdoblju raste (čak i preko deset - naselje Mrzli Dolac), to nije slučaj i s manjim župskim naseljima (jer na mnogim kućnim brojevima broj nuklearnih obitelji pada). Tako da ne možemo govoriti o širem fenomenu širenja naselja i povećanja broja nuklearnih obitelji po svim kućnim brojevima unutar Župe, već prije o porastu onih naselja koja u razmatranom razdoblju već od ranije prednjače po svojoj brojnosti. (Tab. 1, 2, 3) Obzirom da, kao što vidimo, istovremeno u manjim naseljima stagnira broj kućišta, za pretpostaviti je kako su manja naselja u tom razdoblju stoga gravitirala većima (Mrzli Dolac, Krivi Put), te da je osnivanje novih kućnih brojeva u drugoj polovici 19. stoljeća značilo prije svega preseljenje jednog dijela nuklearnih obitelji u veća naselja unutar Župe, ili pak podjelu zadruga na manje obitelji. Porast kućnih brojeva i osnivanje novih kućišta omogućava u to vrijeme i zakonska regulativa u Kraljevini Hrvatskoj i Slavoniji, odnosno, Temeljni zakon za Vojnu krajinu iz 1807. godine, kojim se nastanak novih kućanstava, pod propisanim uvjetima, omogućava $^{48}$. Doduše, u praksi diobu nije bilo jednostavno izvršiti pravnim putem, to je iziskivalo zahtjevnu pravnu proceduru ${ }^{49}$, a i demografski pritisak na kućanstva na početku 19. stoljeća nije bio presudan faktor diobama $^{50}$. Demografski porast stanovnika, uz postojeću zakonsku regulaciju dioba $z a d r u g a^{51}$, na području župe Krivi Put kreće izražajnije od polovice 19. stoljeća, što nam potvrđuju i podaci iz stališa duša. To se poklapa i s porastom registriranih dioba zadruga ${ }^{52}$, koje su se od tada formalno morale odvijati prema tek donesenom zakonu - Ustavu Krajiškom o kućnim zadrugama iz 1848. godine i prema Krajiškom temeljnom zakonu iz 1850. godine (Pavličević 1989: 280-283).

\section{DIJAGRAMI OBITELJI PREMA POJEDINIM KUĆNIM BROJEVIMA}

$\mathrm{N}$

akon utvrđivanja kretanja broja obitelji po pojedinim kućnim brojevima i naseljima na području Župe, uvidjeli smo kako je suživot dviju nuklearnih obitelji po kućištima, u promatranome razdoblju, prednjačio nad ostalim oblicima stanovanja, da su mnogoobiteljska i mnogočlana kućišta bila rijetkost, te da se broj članova mogao znatno izmijeniti već unutar jednoga stoljeća. (Tab. 1) Primjer tome je kućni broj 2 u Mrzlom Dolcu: na tom je kućištu u prvoj polovici 19. stoljeća živjelo 6 nuklearnih obitelji, a nakon toga broj se uvećao na 17.

Pojedine smo obitelji, koje ćemo opisati u nastavku priloga te prikazati grafički ${ }^{53}$, izabrali sljedećim kriterijem: veći broj obitelji donosimo iz najvećega župskoga naselja (Krivi Put), a po jedan primjer iz nekih manjih naselja (Šojatski Dolac, Veljun).

48 Usporedi Pavličević 1989: 274-279.

49 Usp. podatak s onima o lumerima i tajnim diobama u prilogu Tihane Rubić i Danijele Birt o obiteljskim odnosima u ovom svesku Monografije, poglavito u odlomku naslova Podjela obiteljske imovine.

50 Usp. demografske podatke u prilogu Dragice Husanović-Pejnović i Dane Pejnovića u ovom svesku Monografije.

51 U etnološkoj literaturi nailazimo na složenicu seljačke obiteljske zadruge (Gavazzi et. al. 1960, 1992); u povijesnoj i pravnoj literaturi korišsten je termin kućne zadruge (Pavličević 1989; Utješenović Ostrožinski 1988). U pravnoj je litaraturi taj pojam različit u svom značenju spram seljačkih radnih zadruga, odnosno poslijeratnog socijalističkog radnog, poljoprivrednog udruživanja (zadrugarstva).

52 Treba pritom imati na umu kako je već prilično velik broj formalno obavljenih dioba, a da je pored toga poznato da se velik dio dioba odvijao i u tajnosti, bez formalne, pravno registrirane provedbe. Vidi više o tome u prilogu o obiteljskom životu, suautorica Danijele Birt i Tihane Rubić, u odlomku naslova Podjela obiteljske imovine, u ovom svesku Monografije.

53 Dijagrame smo izradili na temelju podataka iz Stališa duša. 
Kako smo ranije istaknuli, broj osoba i nuklearnih obitelji, po pojedinom kućištu, nije statičan čak niti u pedesetogodišnjem razdoblju. (Tab. 1) ${ }^{54}$ Iz dijagrama koje donosimo u nastavku priloga, razvidno je kako su, po pojedinom kućištu, od sedamdesetih godina 18. stoljeća do sedamdesetih godina 19. stoljeća, najčešće živjele četiri generacije koje su se prosječno smjenjivale svakih 25 godina, a životna je dob članova bila oko 60 godina. ${ }^{5}$

Pri «čitanju» dijagrama koji slijede, treba biti oprezan pri donošenju zaključka o broju članova po jednom kućištu u jednom vremenskom razdoblju. Letimičnijim bismo „čitanjem“ dijagrama mogli pomisliti kako je riječ o istovremenosti življenja prikazanih članova na jednom kućnom broju. Oprezniji će čitatelj, prema godinama rođenja i umiranja, utvrditi kako je ovo ipak prikaz osoba koje su evidentirane po pojedinom kućanstvu za stoljetno razdoblje. Te su se osobe prirodno smjenjivale: umirale i rađale. Tako primjerice dijagram za kućni broj 23 u naselju Krivi Put, obrati li se pažnja na godine rođenja (i umiranja), gdje ih ima ${ }^{56}$, pokazuje kako tek jedan dio prikazanih članova čini skupinu koja je u jednom trenutku živjela zajedno na jednom kućištu (trogeneracijska obitelj) (Dijag. 1): muškarac rođen 1789. godine, žena rođena 1802. godine (najstarija generacija); njihovo četvero djece, od čega dva sina sa suprugom (srednja generacija) i jedno žensko dijete najstarijega sina, rođeno 1846. godine. Već iduće žensko dijete najstarijega sina, rođeno 1848. godine, nije bilo suvremenicom muškarca rođenog 1789. godine, jer on godinu dana ranije umire.

U nastavku rada donosimo nekoliko izabranih primjera obitelji s ciljem da se u ovom dijelu priloga sada usredotočimo na «obiteljske slučajeve» kako bismo s jedne strane prepričali (u tekstu), a s druge strane grafički prikazali (dijagramima) raznovrsnost unutarnjih obiteljskih prilika, dinamiku širenja i smanjenja broja članova, učestalost smrtnosti male djece, kao i dinamiku ponovnih udaja i ženidaba nakon smrti bračnoga druga.

\section{1. OBITELJ NA KUĆNOM BROJU 4, ŽUPSKO NASELJE KRIVI PUT}

Na ovom kućištu možemo također pratiti četiri generacije za stoljetno razdoblje i imamo podatke o postojanju sedam obitelji. Do polovice 19. stoljeća na ovom je kućnom broju živjelo pet obitelji, a nakon toga ostale su dvije. Razlog tomu je nejasan; možemo pretpostaviti da je došlo do iseljavanja. ${ }^{57}$

Najstariji muškarac rođen je 1804. godine. Živio je 75 godina. Oženio se u dobi od 25 godina ženom iste dobi. Imali su petero djece, dvoje muške i troje ženske djece. Jedno muško dijete umrlo je u prvoj godini života.

Sin rođen 1832. godine ženio se prvi put u dobi od 25 godina ženom u dobi od 24 godine. Imali su petero muške djece. Nema podataka o razlogu zbog kojeg je umrla prva žena u dobi od 36 godina, može se pretpostaviti da je umrla pri porodu. Jedno muško dijete umrlo je u dobi od 22 godine u [Slavonskom] Brodu u bolnici. Ostala četvorica sinova osnivaju svoje obitelji. Sin rođen 1858. godine oženio se u dobi od 24 godine ženom iste dobi. Žena umire godinu dana kasnije. Može se pretpostaviti da umire pri porodu jer je u godinu dana braka rodila jedno (muško) dijete, koje kasnije umire u prvoj godini života. Iste godine, tri mjeseca nakon smrti prve žene, muškarac se ženi drugi put ženom starom 19 godina. Imaju troje djece, dva sina i kćer.

54 Moramo napomenuti kako podaci koje iznosimo djelomično predstavljaju krnje podatke jer ovdje ne uzimamo u obzir podatke prije promatranog razdoblja, a niti one koji slijede. No, istraživanje u okviru ovakvog, manjeg priloga nužno se moralo u dijakronijskom smislu ograničiti.

55 Iz prikazanih podataka vidjet ćemo da je samo jedna žena doživjela 80 godina.

56 U dijagrame smo uvrštavali sve podatke kojima smo iz Stališa duša raspolagali. Tamo gdje nije navedena, primjerice, godina smrti, znači da niti u izvorima taj podatak ne nalazimo.

57 Nema izravno pribilježenog podatka da je netko iselio, ali po podatku da je jedan član obitelji umro $u$ [Slavonskom, op.a.] Brodu u bolnici, pretpostavljamo da su se neke obitelji u to vrijeme već bile iselile u Slavoniju. Više o iseljavanju u Slavoniju vidi u prilogu o migracijama Marijete Rajković u prvom svesku Monografije, str. 95-119. 
Sin rođen 1861. godine oženio se, u dobi od 27 godina, dvije godine starijom ženom. Imali su jedno žensko dijete, koje umire u dobi od jedne godine. Iste godine umire i žena, u dobi od 32 godine. U dobi od 31 godinu muškarac se oženio drugom ženom starom 22 godine, s kojom nije imao djece.

Sin rođen 1863. godine oženio se u dobi od 23 godine ženom od 19 godina. Imali su četvero djece, troje ženske i jedno muško dijete. Ono umire u dobi od jedne godine, a još jedno žensko dijete u dobi od 2 godine.

Sin rođen 1869. godine oženio se u dobi od 22 godine ženom starom 21 godinu. Žena umire u 22 godini. Nisu imali djece. Drugi puta se ženi u dobi od 23 godine ženom starom 19 godina.

Muškarac rođen 1832. godine oženio se drugi puta u dobi od 39 godina ženom starom 25 godina, i s njom je imao petero djece, tri sina i dvije kćeri. Dvoje muške djece umire pri porodu, a jedno žensko dijete u dobi od 3 godine. Druga žena umrla je u dobi od 33 godine. Jedna se kći udaje u dobi od 19 godina.

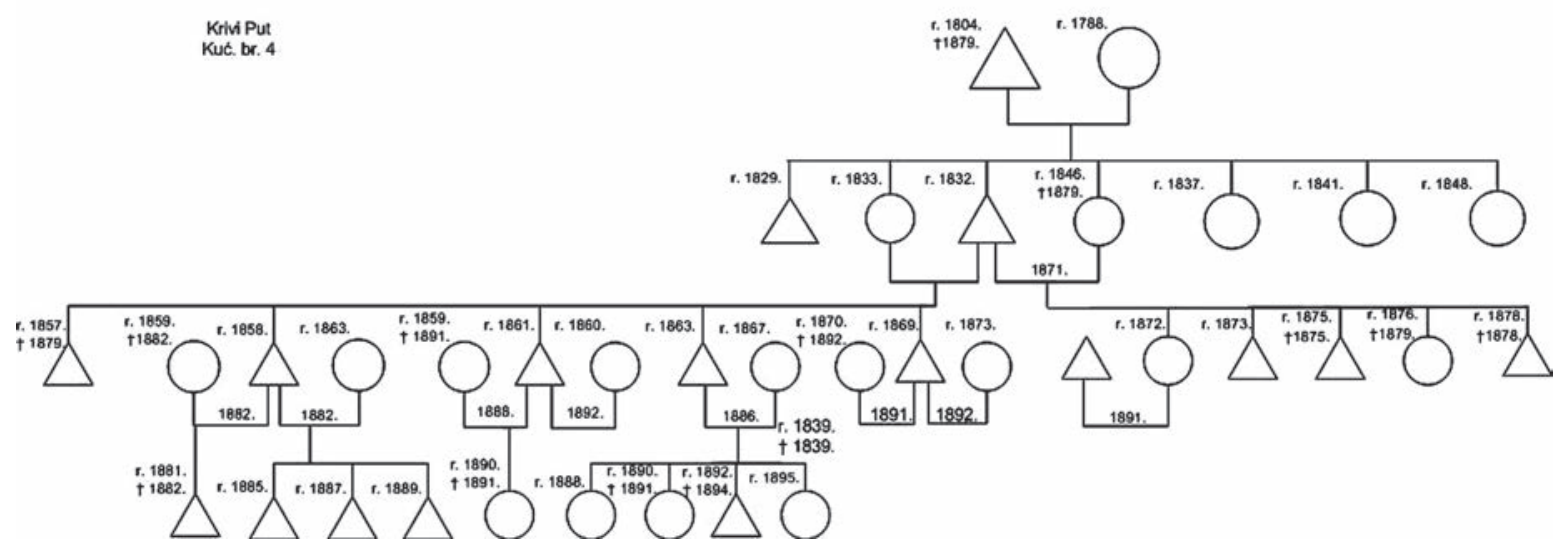

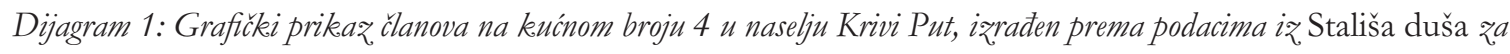
razdoblje 1770-1852. g. i 1800-1890. g. Graficki prikaz izradio M. Vuković, 2009.

\subsection{OBITELJ NA KUĆNOM BROJU 23, ŽUPSKO NASELJE KRIVI PUT}

$\mathrm{Na}$ ovom kućnome broju uviđamo pet generacija i imamo podatke o postojanju četiri obitelji. Najstariji muškarac rođen je 1789. godine i oženio se ženom rođenom 1802. godine. Od žene je bio stariji 13 godina. Imali su četvero djece, troje muških i jedno žensko. Prvo dijete žena rađa u svojoj 17 godini. Muškarac umire u dobi od 58 godina, a žena u dobi od 48 godina, tri godine poslije muža.

Jedan sin, rođen 1825. godine, ženi se, zabilježeno je, ali podataka o ženi nema. Imali su četvero djece, troje ženskih i jedno muško. Muškarac je umro u dobi od 66 godina. Drugi sin također se ženi, ali je iselio u Brod na Savi u Brodskoj regimenti [Slavonski Brod, op.a.], pa nema nikakvih daljnjih podataka o toj obitelji.

Sin rođen 1854. godine ženi se u dobi od 19 godina ženom od 18 godina. S 19 je godina rodila prvo dijete, a posljednje s 39 godina. Imali su dvanaestero djece, desetero muških i dvoje ženskih. Petero muške djece je umrlo: jedno pri porodu, jedno u prvoj godini, jedno s 3 godine, jedno s 4 godine i jedno s 8 godina. 


\section{Krivi Put}

Kuc. br. 23

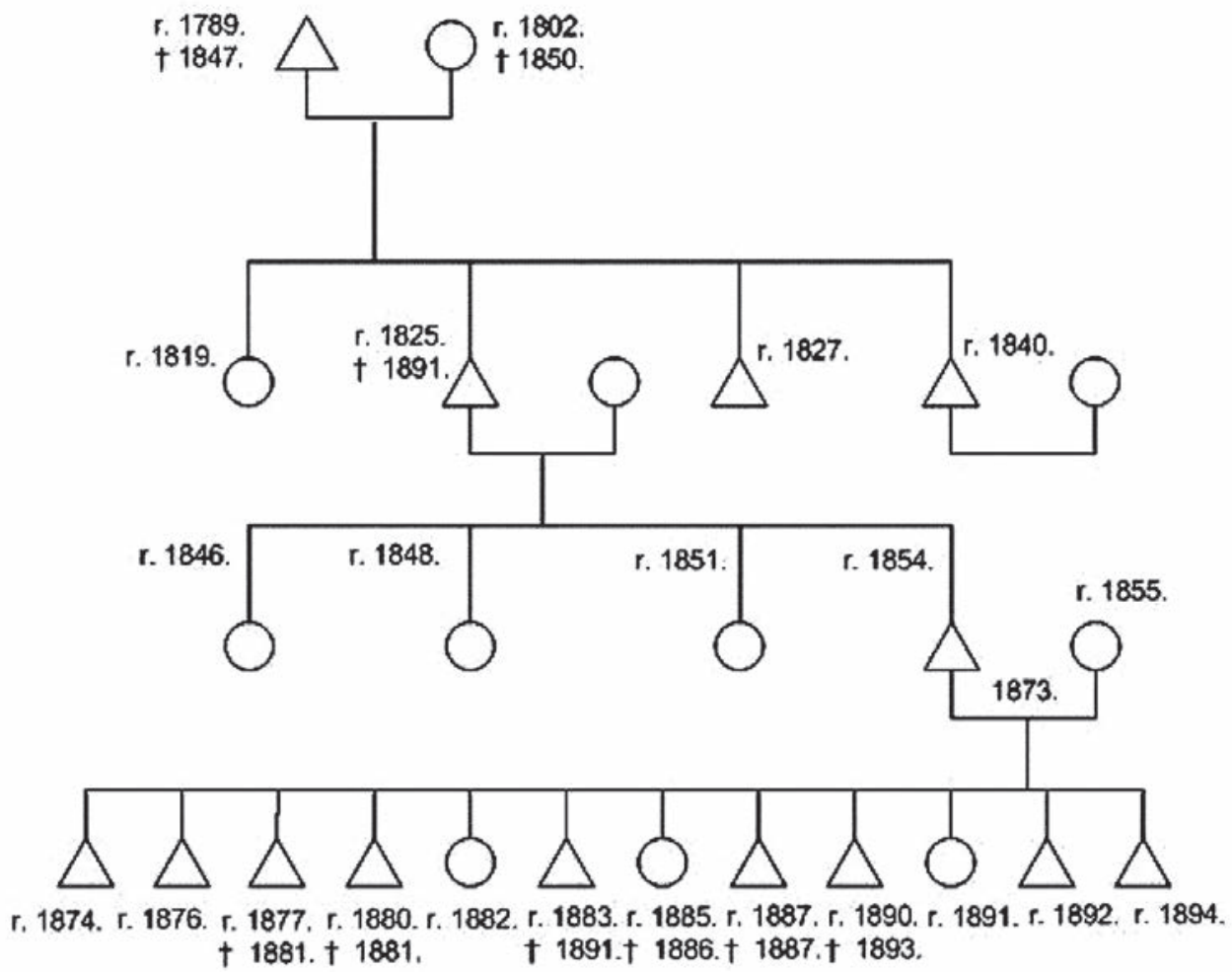

Dijagram 2: Grafički prikaz članova na kućnom broju 23 u naselju Krivi Put, ižrađen prema podacima iz Stališa duša za razdoblje 1770-1852. g. i 1800-1890. g. Graficki prikaz izradila T. Rubic, 2009.

\subsection{OBITELJ NA KUĆNOM BROJU 41, ŽUPSKO NASELJE KRIVI PUT}

Na ovom kućnome broju možemo pratiti četiri generacije i imamo podatke o postojanju 12 obitelji. Najstariji muškarac rođen je 1790. godine i oženio se ženom starijom dvije godine. Muškarac je umro u dobi od 59 godina. Imali su šestero muške djece: prvo dijete rođeno je 1808. godine, a zadnje 1832. godine. Jedno im dijete umire u prvoj godini života.

Sin rođen 1808. godine oženio se ženom rođenom iste godine, koja je umrla u 38. godini života. Imali su petero djece: troje muških i dvoje ženskih. Prvo dijete im se rađa 1831. godine, u njihovoj 23. godini života. Jedno žensko i jedno muško dijete umiru u prvoj godini života. Jedanaest mjeseci poslije umire i žena. Njihov sin, rođen 1836. godine, dobiva muško dijete u dobi od 32 godine, a to se dijete ženi u 24. godini. Muškarac rođen 1808. godine, nakon smrti njegove prve žene, ponovno se ženi i to ženom rođenom 1813. godine. Imali su troje djece: dvoje muške (od kojih jedno umire u prvoj godini života) i jedno žensko dijete. Prvo dijete žena rađa godinu dana nakon smrti suprugove prve žene.

Sin rođen 1811. godine ženi se ženom rođenom 1815. godine. Prvo se dijete rađa 1834. godine. Imali su četvero djece: troje muških i jedno žensko dijete.

Sin rođen 1818. godine ženi se ženom rođenom 1819. godine. Imali su četvero djece: troje muških i jedno žensko dijete. Prvo dijete im se rađa 1842. godine, a jedno muško dijete umire u prvoj godini života.

Sin rođen 1829. godine oženio se u dobi od 22 godine ženom starom 23 godine. Ona umire u dobi od 66 godina. Imali su četvero djece: dvoje muške i dvoje ženske. Prvi sin, rođen 1857. godine, ženi se u dobi od 22 godine ženom iste dobi. Žena umire u dobi od 25 godina. Imali su jedno muško dijete. Drugi 
put se muškarac ženi u dobi od 27 godina ženom od 23 godine, ali nemaju djece. Muškarac umire u dobi od 28 godina, a žena se ponovno udaje u istom mjestu. Drugi sin rođen 1858. godine ženi se u dobi od 25 godina ženom od 20 godina. Imali su šestero djece: dvoje muške i četvero ženske. Dvoje ženske djece umire u prvoj godini života. Prvo dijete rođeno je 1884. godine, a zadnje 1895. godine. Postoji podatak da se jedna od dviju preživjelih kćeri udala u dobi od 18 godina te da je umrla dva mjeseca nakon vjenčanja.

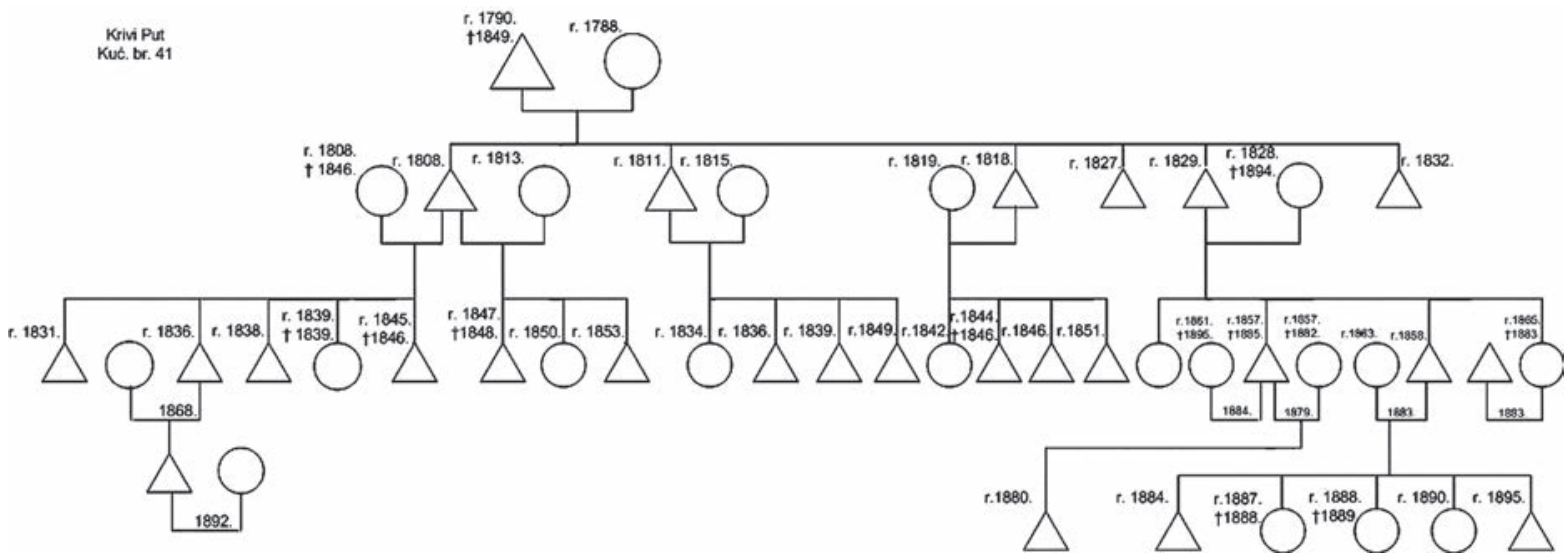

Dijagram 3: Grafički prikaz članova na kućnom broju 41 u naselju Krivi Put, ižaden prema podacima iz Stališa duša za razdoblje 1770-1852. g. i 1800-1890. g. Graficki prikaz izradio M. Vuković, 2009.

\subsection{OBITELJ NA KUĆNOM BROJU 53, ŽUPSKO NASELJE ŠOJATSKI DOLAC}

$\mathrm{Na}$ ovom kućnom broju možemo pratiti četiri generacije u stoljetnom razdoblju i imamo podatke o postojanju pet obitelji. Najstariji muškarac rođen je 1767. godine, a umro je u dobi od 80 godina. Nema podataka o ženi, niti o ženidbi. Imao je troje djece: dvoje muških i jedno žensko koje umire u dobi od dvije godine (u Zagrebu). Prvo dijete s ženom za koju nemamo podataka, imao je s 27 godina.

Prvi sin, rođen 1794. godine, ženi se godinu dana mlađom ženom. Imali su troje djece: jedno muško i dvoje ženske. Prvo dijete žena je imala s 28 godina (1823. godine). Njihov sin rođen 1827. godine oženio se u dobi od 23 godine ženom od 24 godine.

Drugi sin, rođen 1798. godine, oženio se 11 godina mlađom ženom. Ta žena umire, a on se ženi drugi puta, o čemu nema detaljnijih podataka. Postoje samo podaci o djeci: s drugom ženom je imao dvoje djece muško i žensko. Prvo dijete s drugom ženom dobiva u 38 godini života. Žensko dijete umire u dobi

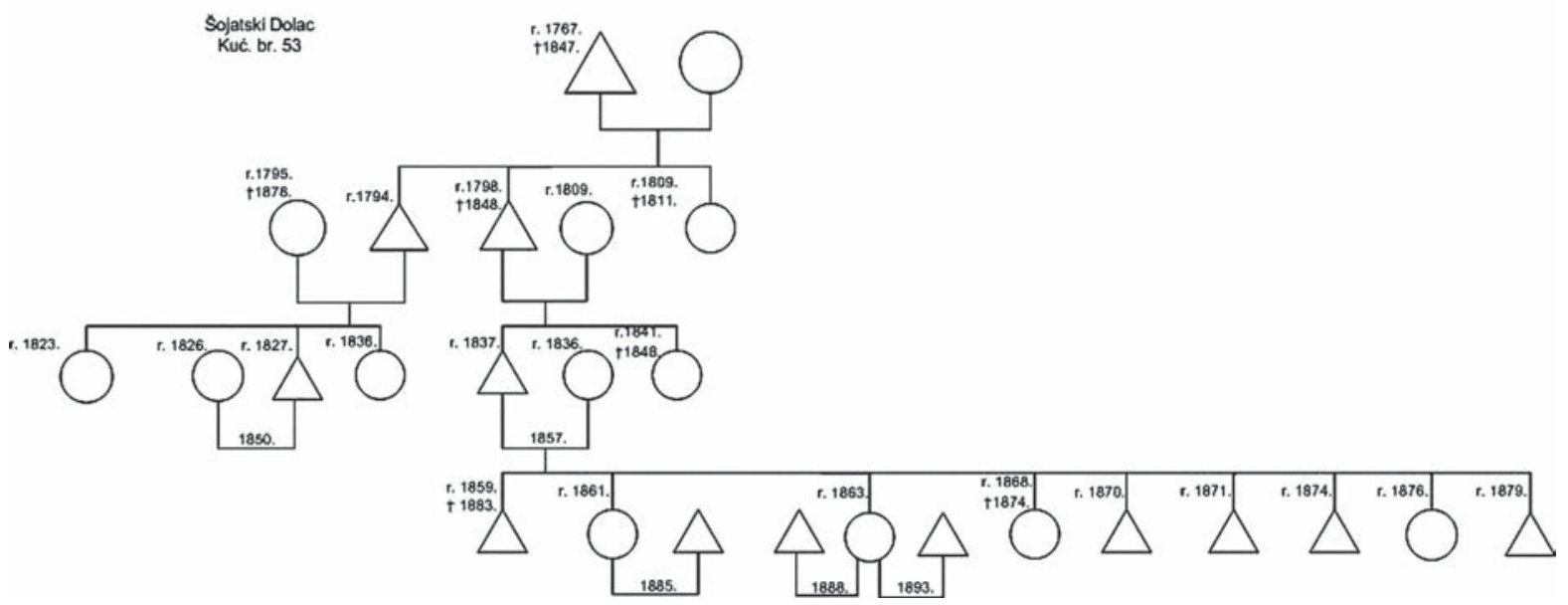

Dijagram 4: Grafički prikaz, članova na kućnom broju 53 u naselju Šojatski Dolac, iæraden prema podacima i₹. Stališa duša za razdoblje 1770-1852. g. i 1800-1890. g. Graficki prikaz izradio M. Vukovic, 2009. 
od 7 godina. Sin rođen 1837. godine, ženi se u dobi od 20 godina ženom od 21 godinu. Imali su devetero djece: četiri ženske i petoricu muške djece. Jedno muško dijete utopilo se (u Otočcu) u 24 godini života, a jedno žensko dijete umire u dobi od 6 godina. Postoje podaci o udaji dviju kćeri: jedna se udaje u dobi od 24 godine, a druga kćer ima dva braka; prvi put se udaje u dobi od 25 godina, a drugi put u dobi od 30 godina i to u istu kuću u koju joj se udala sestra (obje su se udale u Krivi Put).

\subsection{OBITELJ NA KUĆNOM BROJU 68, ŽUPSKO NASELJE VELJUN}

Na ovom kućištu možemo pratiti četiri generacije i imamo podatke o postojanju 7 obitelji. Najstariji muškarac, rođen 1781. godine, imao je šestero muške djece. Prvo je dijete dobio u dobi od 26 godina. Nema nikakvih podataka o ženi s kojom je imao djecu.

Njegov najstariji sin, rođen 1807. godine, oženjen je ženom iste dobi i o njemu nema više podataka, pa možemo pretpostaviti da je iselio iz Župe.

Drugi sin, rođen 1811. godine, oženio se ženom rođenom 1814. godine, a umro je u 63 godini. Imali su devetero djece: šest muške i troje ženske. Jedno žensko dijete umire u dobi od 16 godina. Prvo dijete rođeno je 1836., a zadnje 1870. godine, a o njihovom daljnjem životu nema nikakvih podataka, osim onog da je jedan muški član ove obitelji odsutan. Pretpostavljamo da je obitelj iselila.

Treći sin, rođen 1816. godine, oženio se ženom rođenom 1818. godine. Imali su dvoje ženske djece. Prvo dijete su dobili 1840. godine.

Četvrti sin, rođen 1827. godine, oženio se ženom rođenom 1828. godine. Imali su jedno žensko dijete koje umire kao novorođenče. Iste godine umire i otac.

Sin rođen 1830. godine oženio se u dobi od 23 godine ženom od 19 godina. Imali su troje muške djece. Prvo dijete se rodilo 1861. godine. Jedno dijete umire u dobi od 20 godina. Sin rođen 1861. godine oženio se u 21. godini ženom od 18 godina. Imali su petero djece: dvoje muških i troje ženskih. Jedno žensko dijete umire u prvoj godini života.

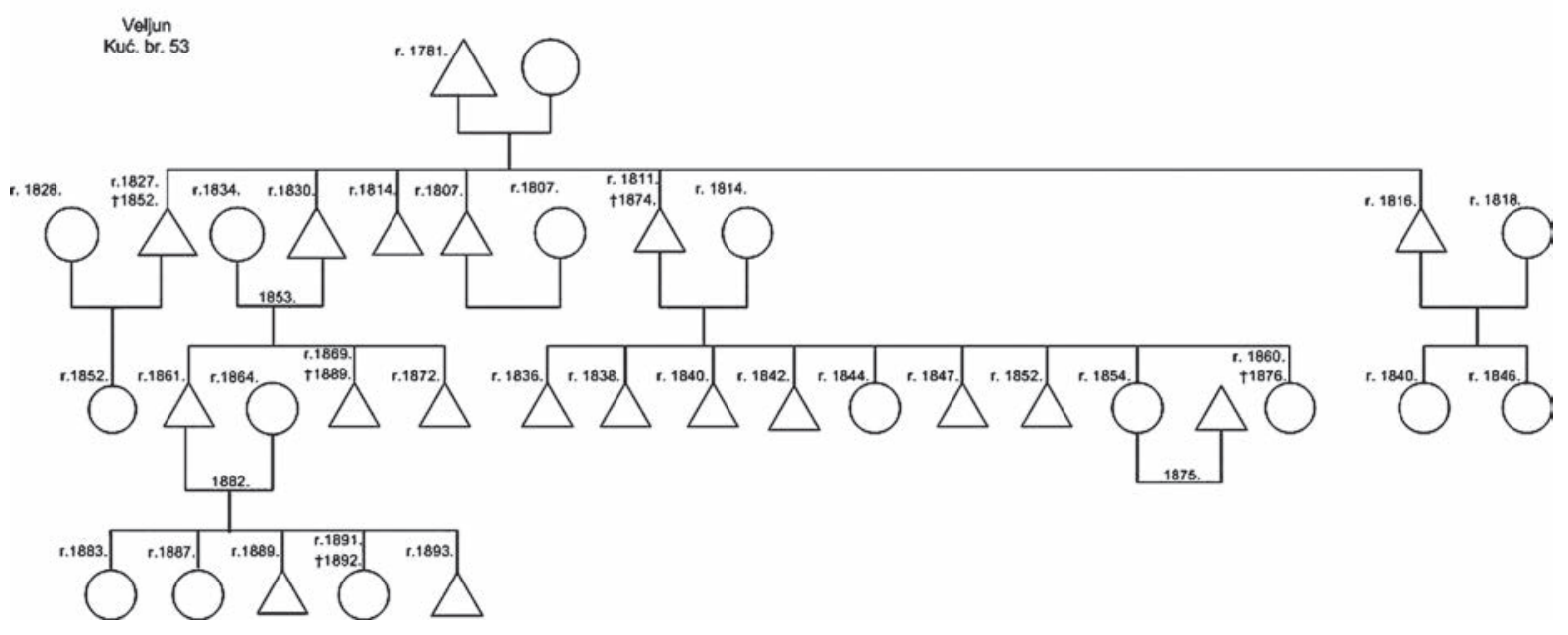

Dijagram 5: Grafickei prikaz članova na kúnom broju 68 u naselju Veljun, ižraden prema podacima iz. Stališa duša za razdoblje 1770-1852. g. i 1800-1890. g. Graficki prikaz izradio M. Vukovic, 2009.

\section{ANALIZA IZABRANIH OBITELJI}

bzirom na spomenut ograničeni doseg informacija koji nudi korištena vrsta izvora, možemo govoriti samo o nekim općenito uočenim karakteristikama prikazanih, izabranih kućišta. 
Smrtnost žena u dvadesetim, tridesetim i četrdesetim godinama života puno je češća od smrtnosti muškaraca iste dobi. Razlog tome vjerojatno su komplikacije izazvane porodima jer riječ je o udanim ženama u reprodukcijskoj dobi, što se razvidno iz podataka iz Stališa duša. Smrtnost žena u dobi od pedeset godina puno je rjeđa.

Najveća stopa smrtnosti je kod novorođenčadi i djece u prvoj godini života, a samo je neznatno manja do sedme godine života. Kod djece od deset do dvadeset godina smrtnost je također vrlo visoka. Uzroci smrti novorođenčadi i djece u prvoj godini života povezani su zasigurno s poteškoćama prilikom i neposredno nakon poroda, koje su u prikazanom razdoblju bile uobičajena pojava, vjerojatno velikim dijelom uslijed malog broja liječnika. ${ }^{58}$ (usp. Glesinger 1967/1968:237) Treba imati u vidu i drugačije higijensko-epidemiološke i zdravstvene prilike ovog područja u promatranom razdoblju (usp. ibid.) Bolesti poput plućne tuberkuloze, tada su bile čestim uzrokom velike stope smrtnosti ne samo djece i mladih, već i odraslih (usp. ibid.:223).

Iz prikazanih podataka, uglavnom vidimo bračni status muškaraca unutar obitelji, a samo ponekad imamo podatke o bračnom statusu žena. Gledajući odrasle muškarce koji žive na kućištima, vidimo kako većina stupa u brak. Za one muškarce gdje nema podataka o bračnom statusu, a nisu umrli kao djeca ili mladi, možemo samo pretpostaviti da su se iselili s kućišta ili su ostali neoženjeni ${ }^{59}$, a što se, prema mjestimično zapisanim podacima u stališima duša, i potvrđuje. Sukladno tome možemo zaključiti da je takvo stanje bilo i sa ženama, za koje podaci nakon odrastanja, i u dobi za udaju, nisu dalje bilježeni. Upravo bi za provjeru ovih pretpostavki trebalo konzultirati knjige umrlih, krštenih i vjenčanih, u kojima postoji opaska kada su umrli i, u slučaju da su iselili, gdje su iselili.

Česta je pojava drugi brak i kod muškaraca i kod žena. To se događalo isključivo nakon smrti prvoga bračnoga druga. Već je iz kazivanja Krivopućana uočeno kako su udovac ili udovica, koji bi ostali sami s puno djece, bili primorani stupiti u novi brak, kako bi zbrinuli i prehranjivali mnogobrojnu djecu. ${ }^{60}$ Kako su žene vrlo često umirale pri porodu, a dobna razlika među djecom u obitelji bila je najčešće oko dvije godine, muškarcu s malom djecom druga je žena bila nužna. Ženi koja je sama s djecom, muškarac je, u patrijarhalnom društvu, također bio izuzetno potreban kako bi preživjeli. ${ }^{61}$ Tako imamo primjer ponovne ženidbe i udaje svega mjesec ili dva nakon smrti bračnoga druga.

Od cjelokupnih podataka iz Stališa duša, samo na jednom kućištu pratimo dva rodonačelnika (kućni broj 2, naselje Mrzli Dol), dok sva ostala kućišta imaju jednog rodonačelnika. Na svakom je kućištu obiteljska struktura različita, ponajprije s obzirom na broj nuklearnih obitelji i broj generacija u stogodišnjem razdoblju.

Dob stupanja u brak najčešće je između dvadesete i tridesete godine života. ${ }^{62}$ Ono što primjećujemo je da žene stupaju u brak katkad ispod dvadesete godine života, čak od šesnaeste i sedamnaeste godine. Muškarci stupaju u brak iznad dvadesete godine, ali najč̌šća dob stupanja u brak muškaraca je iznad dvadeset pete godine života. Možemo primijetiti da ima dosta muškaraca koji stupaju u brak čak nakon

58 Nedostatan broj liječnika, iako vrlo cijenjeni i poznati poimenice, u dokumentima koji se spominju u prilogu Lavoslava Glesingera, razvidan je za Senj (Glesinger 1967/1968). Za pretpostaviti je da je senjska okolica (pa tako i Krivi Put) još znatnije oskudijevala u dostupnosti liječnika.

59 O starim (neoženjenim) dečkima i (neudatim) curama vidi u knjizi o svadbenim običajima Krivopućana (u tisku).

60 Usporedi podatke s onima u prilogu suautorica Tihane Rubić i Danijele Birt o obiteljskim odnosima, u ovom svesku Monografije.

${ }_{61}$ Usporedi s podatkom da bi neki muškarac iz sela znao pomagati ženi s djecom (primjerice, udovici ili onoj čiji je muž duže odsutan na radu u prekooceanskim zemljama) u poslovima oko prodaje na sajmu, koji donosi Tihana Rubić u prilogu o tradicijskoj trgovini i sajmovima, u prvom svesku Monografije, str. 331-332. Također su muškarci nedjeljom, inače neradnim danom, besplatno pomagali udovicama oko većih poljodjelskih poslova: košnja trave, žetva i sl. Vidi u prilozima u cjelini o gospodarstvu, autorice Marijete Rajković u prvom svesku Monografije, str. 209.

62 Usporedi s podacima u knjizi o svadbenim običajima Krivopućana (u tisku). 
tridesete godine. Muškarci su uglavnom stariji od žena s kojima stupaju u brak (čak do deset godina razlike), ali ima i brakova u kojima su ženici istih godina i brakova kada su žene starije od muškarca: nerijetko susrećemo i primjere da je žena dvije ili tri godine starija od muškarca. U slučajevima kada muškarac stupa po drugi puta u brak, druga žena je u pravilu mlađa od njegove prve žene.

Prema mjestimičnim podacima u izvoru, vidimo kako se bračni partner birao u samom mjestu življenja ili unutar Župe. Tek se u pojedinim slučajevima žena udala izvan Župe (u Senj ili Otočac) ili da se muškarac oženio ženom iz druge Župe (iz Brloga). Ipak, kako su ti podaci tek sporadični, možemo zaključiti ili da nisu dosljedno bilježeni ili da se doista uglavnom radi o endogamiji unutar mjesta i unutar crkvene župe, a što potvrđuju etnološka terenska istraživanja na krivoputskome području. ${ }^{63}$ Za provjeru ovih podataka najpouzdaniji izvor bile bi matične knjige vjenčanih.

Broj rođene djece u promatranom razdoblju uglavnom se kretao od petero do desetero po obitelji ${ }^{64}$, ali bilo je obitelji gdje je taj broj bio manji, kao i onih gdje je bio veći. Ono što se u analizi izvora primjećuje jest velik mortalitet djece; u svakoj obitelji s mnogobrojnom djecom vidimo kako je barem jedno dijete umrlo, a često i više njih. U nekim obiteljima gotovo su sva djeca umrla. Iz podataka uočavamo naročito veliku smrtnost male djece polovicom 19. stoljeća, što se uvelike podudara s već poznatim činjenicama o velikoj epidemiji kuge upravo u tom razdoblju, za šire područje okolice Senja (Glesinger 1967/1968: 227).

Mjestimično se događa da je tek natukničkom formulacijom zabilježen podatak za nekog muškarca da je oženjen i da imaju toliko i toliko djece. Pretpostavljamo u tom slučaju da su ti muškarci, ili čitava nuklearna obitelj, iselili. O tome nam na nekim mjestima govore i izravne bilješke: odsutan; iselio. Na nekoliko mjesta imamo izrijekom, uže ili šire, navedeno mjesto iseljavanja: Brod na Savi; Slavonija. ${ }^{65} \mathrm{U}$ tom se razdoblju, poznato je, ekonomska i socijalna neodrživost velikog broja obitelji na kućištu, donekle rješavala diobama (formalnim, te tajnim ili dogovornim) ${ }^{66}$, koje su omogućavale migracije u druge krajeve Hrvatske.

\section{ZAKLJUČNA RAZMATRANJA}

Cilj ovog priloga bio je proučiti Stališe duša za župu Krivi Put u sprezi sa spoznajama koje su dobivene temeljem prethodnog terenskog istraživanja obiteljskog života Krivopućana. Proučili smo izvore za župu Krivi Put, koji se odnose na razdoblje od 1829. do 1943. godine.

Stališi duša kao izvor za proučavanje obiteljskih i demografskih promjena imaju vrijednost prije svega za potkrjepu već unaprijed stečenih spoznaja. Iz te vrste izvora izravno možemo iščitati: broj obitelji na pojedinom kućnom broju (jer su župnici s pouzdanom točnošću na taj način odvajali pojedine obitelji; prema objektu stanovanja). Razvidan je i broj djece unutar obitelji i prema pojedinom kućištu; razvidna je životna dob članova pojedinog kućišta (jer su se precizno bilježile godine rođenja i smrti, a mjestimično i godine sklapanja brakova). Vidljiv je i bračni status pojedinaca i linearno srodstvo unutar obitelji.

Temeljem svega navedenog pri analizi odabranih kućišta dobili smo neke indikatore o broju obitelji, broju djece, prirodnom prirastu, smrtnosti te bračnom statusu. Kako se radi o jednom manjem uzorku, namjera mu nije bila biti reprezentativnim, niti nam je na osnovu njega namjera bila donositi zaključke

63 Usporedi s podacima u knjizi o svadbenim običajima Krivopućana (u tisku).

64 Usporedi podatke iz dvaju tekstova u ovom svesku Monografije: prilogu o demografskim kretanjima, suautora Dragice Husanović-Pejnović i Dane Pejnovića, te prilogu o obiteljskom životu, Tihane Rubić i Danijele Birt, u ovom svesku Monografije.

65 Usporedi valjanost ovih bilješki u odnosu na iscrpne podatke o iseljavanju Krivopućana u tom smjeru, u prilozima o iseljavanju i migracijama, Marijete Rajković, str. 79-92 te Marijete Rajković i Jasmine Jurković, str. 95-119, u prvom svesku Monografije.

66 O načinima na koji se mogla odvijati dioba zadružne obitelji, usporedi s prilozima Milane Černelić o dvije zadružne obitelji, te Tihane Rubić i Danijele Birt, u odlomku naslova Podjela obiteljske imovine, u ovom svesku Monografije. 
o obrascima življenja na području Krivoga Puta. Podatke iz Stališa duša kvantitativno smo obradili. Te podatke možemo koristiti kao smjernicu za daljnja istraživanja ili nadopunu i potvrdu terenski sakupljene građe. Za podrobniju analizu i precizniju potkrjepu podataka, nužno je konzultirati ostale arhivske izvore poput matica rođenih, vjenčanih i umrlih. Tek spregom različitih izvora možemo sveobuhvatnije sagledati obiteljske i društvene promjene.

\section{LITERATURA I IZVORI:}

BOGOVIĆ, Mile (2008): Župa Krivi Put. U: ur. Milana Černelić, Marijeta Rajković, Tihana Rubić: Živjeti na Krivom Putu, etnološko-povijesna monografija o primorskim Bunjevcima, 1: 69-75.

ČAPO, Jasna (1991): Vlastelinstvo Cernik: Gospodarske i demografske promjene na hrvatskome selu u kasnome feudalizmu. Zagreb: Institut za etnologiju i folkloristiku.

ČAPO ŽMEGAČ, Jasna (1996): Konstrukcija modela obitelji u Europi i povijest obitelji u Hrvatskoj. Narodna umjetnost 33(2), 179-196.

GAVAZZI, Milovan (1978): Vrela i sudbine narodnih tradicija kroz prostore, vremena i ljude. Zagreb: Sveučilišna naklada Liber.

GLESINGER, Lavoslav (1967/1968): Povijest zdravstva u Senju. Senjski zbornik, 3, Senj: Gradski muzej Senj, 222-249.

HEADY, Patrick (2007): What can anthropological methods contribute to demography - and how? Demographic Research, 16, 555-558, http://www.demographic-research.org/volumes/vol16/18/

HOŠKO, Franjo Emanuel (2004): Popis i stanje župa današnje Gospićko-senjske biskupije 1733. godine.

U. ur. Franjo Emanuel Hoško: Prošlost obvezuje, Povijesni korijeni Gospićko-senjske biskupije, Rijeka:

Teologija u Rijeci, 367-380.

http://rodoslovlje.bloger.hr/post/status-animarum/57376.aspx (pregledano 21. ožujka 2009.)

KOLANOVIĆ, Josip (1995): Hrvaski sabor od narodnih zborovanja do građanskog sabora 1848. U: ur. Željko Sabol: Hrvatski sabor, Zagreb: Sabor RH, Nakladni zavod Globus, Školska knjiga, 9-61.

KORENČIĆ, Mirko (1979): Naselja i stanovništvo SR Hrvatske 1857.-1971, Zagreb: JAZU.

LJUBOVIĆ, Blaženka (2008): Zemljopisni položaj i pregled novije povijesti Krivog Puta. U: ur. Milana Černelić, Marijeta Rajković, Tihana Rubić: Živjeti na Krivom Putu, etnološko-povijesna monografija o primorskim Bunjevcima, 1: 49-67.

PAVLIČEVIĆ, Dragutin (1989): Hrvatske kućne zadruge I. (do 1881.), Zagreb: Sveučilišna naklada Liber.

Stališ duša (Status animarum) za rimokatoličku župu Krivi Put - obuhvaća razdoblje rođenja od 1770. do 1857. godine, bez oznake mjesta i oznake godine, 60 rukom paginiranih stranica.

Stališ duša (Status animarum) za rimokatoličku župu Krivi Put - obuhvaća razdoblje rođenja od 1800. do 1890. godine, bez oznake mjesta i oznake godine, 240 rukom paginiranih stranica.

ŠARIĆ, Marko (2008): Bunjevci u ranom srednjem vijeku-postanak i razvoj jedne predmoderne etnije. U: ur. Milana Černelić, Marijeta Rajković, Tihana Rubić: Živjeti na Krivom Putu, povijesno-etnološka monografija, 1:15-43.

UTJEŠANOVIĆ OSTROŽINSKI, Ognjeslav (1988): Kućne zadruge, Vojna Krajina i Ustav. Zagreb: Stvarnost. 